\title{
AWARENESS, ATTITUDES AND PERCEPTIONS ON EPILEPSY IN SOUTHERN BRAZIL
}

\author{
Asdrubal Falavigna, ${ }^{1,4}$ Alisson Roberto Teles ${ }^{2,4}$, Felipe Roth ${ }^{2,4}$, \\ Maíra Cristina Velho ${ }^{2,4}$, Marcelo Ricardo Rosa Roxo ${ }^{2,4}$, Alexandre Luiz Dal Bosco,4, \\ Roberta Castilhos da Silva ${ }^{2,4}$, Tatiane Carrer ${ }^{3,4}$, Miguel Francisco de Lessa Medina ${ }^{2,4}$, \\ Gustavo Salvati2,4, Cleiton Dahmer 2,4, Maira Basso ${ }^{3,4}$, \\ Viviane Maria Vedana ${ }^{2,4}$, Thaís Mazzocchinn", Gabriela Mosena2,4, \\ Ricardo Gil Ribeiro ${ }^{3,4}$, Tiago Adami Siqueira ${ }^{3,4}$
}

\begin{abstract}
Objective: To verify awareness and attitudes toward epilepsy in Southern Brazil. Method: A questionnaire about familiarity with the disease, awareness and attitudes toward epileptics was applied to 832 inhabitants of Caxias do Sul. The answers were analyzed in three different groups: G1, non-university students; G2, university students up to the second year; and G3, university students with more than two years education and university graduates. Results: University students and graduates are better informed regarding causes and treatment of epilepsy. Moreover, those interviewees present less negative attitudes toward epileptics. However, a large part of that group lacks some basic information on the disease. Conclusion: There is lack of information on epilepsy among Brazilians. Education campaigns should be carried out in order to clarify some aspects concerning epilepsy.
\end{abstract}

KEY WORDS: epilepsy, knowledge, attitudes, questionnaire, Brazil.

\begin{abstract}
Conhecimento, atitudes e percepções sobre epilepsia no Sul do Brasil
RESUMO - Objetivo: Verificar o conhecimento e as atitudes sobre epilepsia na população de Caxias do Sul. Metodo: Foi aplicado um questionário sobre familiaridade com a doença, conhecimentos e atitudes diante de um portador de epilepsia a 832 moradores da cidade. As respostas foram analisadas em três grupos distintos: G1, não-universitários; $\mathrm{G}_{2}$, universitários até o segundo ano; e $\mathrm{G}_{3}$, universitários com mais de dois anos e graduados. Resultados: Os universitários e graduados possuem melhor conhecimento sobre causas e tratamento da epilepsia. Além disso, esses entrevistados apresentam menos atitudes negativas para com o portador de epilepsia. Entretanto, uma boa parte desse grupo apresenta falta de alguns conhecimentos básicos sobre a doença. Conclusão: Há falta de informação à população brasileira sobre epilepsia. Campanhas educacionais devem ser realizadas no intuito de desmistificar alguns aspectos concernentes à epilepsia.
\end{abstract}

PALAVRAS-CHAVE: epilepsia, conhecimento, atitudes, questionários, Brasil.

Although epilepsy is one of the most prevalent neurological pathologies, this subject is surrounded by stigmas and prejudice among the population, awareness and attitudes toward the disease being discussed in many articles ${ }^{1-15}$. It has been observed that much of the discrimination against people with this disease is motivated by the mistaken idea of impotence, fragility and mental impairment of the patient, besides fear of having to witness and deal with a seizure ${ }^{16}$. These actions are not due only to lack of individual information, but also to stigmas prevalent in cul- tures and backward laws in many places throughout the world ${ }^{17}$. In addition, mistaken information concerning epilepsy is still widespread among the population through generations, keeping alive a consensus of unfamiliarity and negative attitudes towards the disease. It is important to know about epilepsy because it helps to demystify individual and familial beliefs, to improve behavior and attitudes regarding the disease, to reduce the emotional impact of having a seizure in front of others and, therefore, to reduce psychosocial wounds and improve the patient's

\footnotetext{
'Professor of Neurology, Universidade de Caxias do Sul, Caxias do Sul RS, Brazil; '2Medical student, Universidade de Caxias do Sul, Caxias do Sul RS, Brazil; ${ }^{3}$ Physiotherapy student, Universidade de Caxias do Sul, Caxias do Sul RS, Brazil; ${ }^{4}$ Liga Acadêmica Multidisciplinar de Neurologia e Neurocirurgia da Universidade de Caxias do Sul, Caxias do Sul RS, Brazil (LAMNN-UCS).
}

Received 14 February 2007, received in final form 24 August 2007. Accepted 20 September 2007. 
social environment, conditions and consequently their quality of life. Suurmeijer and coworkers, for example, demonstrated that self-perception of stigma, psychological stress and social isolation are factors associated with quality of life in patients with epilepsy, independent of their clinical state ${ }^{18}$.

Studies that qualify notions about epilepsy in society demonstrate that despite the improvement in attitudes and knowledge about this disorder in some countries ${ }^{1,9,13}$, children and adults are still discriminated by mistaken beliefs, promoting prejudicial social attitudes towards them ${ }^{17}$. Brazilian publications conclude that people do not have a satisfactory understanding of epilepsy, indicating that the information acquired is superficial and that it is necessary to clarify people concerning this issue at all socioeconomic levels ${ }^{7,15,19-22}$.

This study in the southernmost region of Brazil was guided by the need to aggregate data in the literature about awareness of epilepsy among the population. For this reason an assessment instrument was developed mostly with questions already used by other researchers: 1 - age, gender, income and level of schooling; 2 -familiarity with the disease; 3 -knowledge on etiology and treatment; 4 - attitudes in dealing with an epileptic. Therefore, this study aims to look at knowledge, attitudes and perceptions on epilepsy among people in Caxias do Sul, Brazil, and compare our data with other studies described the literature.

\section{METHOD}

The sample was collected at two locations: Community Actions, promoted by Universidade de Caxias do Sul (UCS) in six neighborhoods of the city of Caxias do Sul, and college students from five courses in the field of health care (medicine, $n=154$; nursing, $n=66$; physiotherapy, $n=67$; nutrition, $n=26$; and psychology, $n=104$ ). Community Actions are events in a project carried out by UCS, intending to provide information and services in medicine, social welfare, law, biology, psychology and physical education to com- munities in the local neighborhoods and towns of the region. The questionnaires were applied to the university students during class.

The inclusion criteria were: being over the age of 16 , having some schooling and agreeing to participate in the survey by signing a letter of consent. At the end of the interview they were given an explanatory leaflet written by Liga Acadêmica Multidisciplinar de Neurologia e Neurocirurgia da Universidade de Caxias do Sul. The leaflet had general information on epilepsy, including epidemiology, causes, treatments and psychosocial aspects.

The sample was divided into three groups to analyze the results: group 1, G1: non students; group 2, G2: students until the second year of the course; and group 3, G3: third year students and above and graduates. Afterwards, the influence of age on the answers was analyzed splitting $\mathrm{G}_{1}$ into three subgroups: G1A, 17-30 years; G1B, 31-50 years; and $\mathrm{G}_{1} \mathrm{C}$, more than 50 years old.

The statistical analysis was performed with SPSS $^{\circledR}$ for Windows (SPSS Inc., Chicago, IL, USA). The categorical variables were presented as proportions and the age as mean and standard-deviation. For the univaried analysis the Chi-square test was used in qualitatives variables and the Kruskall-Wallis test was used to compare the age averages.

The study was submitted to the Ethics and Research Committee of UCS and began after approval.

\section{RESULTS}

Eight hundred and thirty-two people were interviewed in all: $35.9 \%(n=299)$ belonged to $G_{1} ; 46.0 \%$ to $\mathrm{G}_{2}(\mathrm{n}=383)$; and $18.0 \%(\mathrm{n}=150)$ to $\mathrm{G}_{3}$. Table 1 shows the general characteristics of the groups studied. Female subjects predominate (73.6\%) and this proportion is observed mainly among the university student groups ( $\mathrm{G}_{2}$ and $\mathrm{G}_{3}$ ). The mean age of $\mathrm{G}_{1}$ was 44.75 years, older than the university students and graduates. It was observed that the level of income is determined by the level of education; $68.2 \%$ of $\mathrm{G}_{1}$ has an income of up to three minimum wages and $53.7 \%$ of the $\mathrm{G}_{3}$ has an income higher than twelve minimum wages.

Table 1. General sample characteristics and familiarity with epilepsy.

\begin{tabular}{|c|c|c|c|c|c|}
\hline & Total $(n=832)$ & $\mathrm{G}_{1}(35.9 \%)$ & $\mathrm{G}_{2}(46.0 \%)$ & $\mathrm{G}_{3}(18.0 \%)$ & $\mathrm{p}$ \\
\hline Female gender & $73.6 \%$ & $60.5 \%$ & $81.5 \%$ & $79 \cdot 3 \%$ & $<0.001$ \\
\hline Age (in years) & $32.21(\mathrm{sd}=14.81)$ & $44.75(s d=14.21)$ & $25.41(\mathrm{sd}=10.43)$ & $24,60(\mathrm{sd}=6.58)$ & $<0.001$ \\
\hline Familiar income & & & & & $<0.001$ \\
\hline Up to 3 wages & $32.8 \%$ & $68.2 \%$ & $14.1 \%$ & $10.0 \%$ & \\
\hline Up to 7 wages & $36.1 \%$ & $2.1 \%$ & $42.8 \%$ & $32.7 \%$ & \\
\hline More than 12 wages & $31.1 \%$ & $2.7 \%$ & $43.1 \%$ & $53.7 \%$ & \\
\hline Heard or read about epilepsy & $88.8 \%$ & $80.2 \%$ & $92.2 \%$ & $97 \cdot 3 \%$ & $<0.001$ \\
\hline Knew someone with epilepsy & $67.2 \%$ & $67.2 \%$ & $67.6 \%$ & $66.0 \%$ & 0.937 \\
\hline Witnessed an epileptic seizure & $58.1 \%$ & $67.2 \%$ & $50.7 \%$ & $58.7 \%$ & $<0.001$ \\
\hline
\end{tabular}


Table 2. Knowledge on epilepsy $(n=832)$.

\begin{tabular}{|c|c|c|c|c|c|}
\hline & Total & G1 & $\mathrm{G}_{2}$ & $\mathrm{G}_{3}$ & $\mathrm{p}$ \\
\hline \multicolumn{6}{|l|}{ Causes of epilepsy } \\
\hline Blood diseases & $7.6 \%$ & $14.0 \%$ & $3.9 \%$ & $4.0 \%$ & $<0.001$ \\
\hline Drug use & $37.6 \%$ & $40.1 \%$ & $32.4 \%$ & $46.0 \%$ & 0.008 \\
\hline Mental disease & $28.8 \%$ & $38.5 \%$ & $19.8 \%$ & $32.7 \%$ & $<0.001$ \\
\hline Accidents & $22.0 \%$ & $24.1 \%$ & $16.7 \%$ & $31.3 \%$ & 0.001 \\
\hline Congenital abnormalities & $25.2 \%$ & $29.1 \%$ & $19.8 \%$ & $31.3 \%$ & 0.004 \\
\hline Hereditary disease & $26.3 \%$ & $33.4 \%$ & $21.1 \%$ & $25.3 \%$ & 0.001 \\
\hline Brain disease & $72.4 \%$ & $71.9 \%$ & $70.0 \%$ & $79.3 \%$ & 0.09 \\
\hline I don't know the cause & $11.3 \%$ & $11.0 \%$ & $13.6 \%$ & $6.0 \%$ & 0.045 \\
\hline \multicolumn{6}{|l|}{ Treatment } \\
\hline Medication & $81.7 \%$ & $66.6 \%$ & $87.5 \%$ & $97.3 \%$ & $<0.001$ \\
\hline Surgery & $22.7 \%$ & $13.7 \%$ & $25 \cdot 3 \%$ & $34.0 \%$ & $<0.001$ \\
\hline Teas and medicinal herbs (Medicinal herbs and teas) & $2.5 \%$ & $5.4 \%$ & $0.8 \%$ & $1.3 \%$ & $<0.001$ \\
\hline There is no treatment & $4.6 \%$ & $9.0 \%$ & $2.9 \%$ & 0 & $<0.001$ \\
\hline I don't know what the treatment is & $13.0 \%$ & $22.4 \%$ & $9.7 \%$ & $2.7 \%$ & $<0.001$ \\
\hline What would you do if a patient had a seizure? & & & & & $<0.001$ \\
\hline Keep away from the epileptic patient & $1.1 \%$ & $2.3 \%$ & $0.5 \%$ & o & \\
\hline Hold the person, to try contain the patient & $11.4 \%$ & $20.1 \%$ & $8.1 \%$ & $2.7 \%$ & \\
\hline Move away objects that could hurt the patient & $49 \cdot 3 \%$ & $41.8 \%$ & $51.4 \%$ & $58.7 \%$ & \\
\hline $\begin{array}{l}\text { Put something inside the patient's mouth, } \\
\text { so that the person won't asphyxiate }\end{array}$ & $37.1 \%$ & $33.1 \%$ & $39.7 \%$ & $38.7 \%$ & \\
\hline Throw water at the patient & $1.1 \%$ & $2.7 \%$ & $0.3 \%$ & o & \\
\hline After a seizure, you must & & & & & $<0.001$ \\
\hline Force the patient to eat & $0.2 \%$ & $0.3 \%$ & $0.3 \%$ & 0 & \\
\hline Force the patient to exercise & $5 \cdot 3 \%$ & $10.0 \%$ & $3.1 \%$ & $1.3 \%$ & \\
\hline Leave the patient to rest & $94.5 \%$ & $89.6 \%$ & $96.6 \%$ & $98.7 \%$ & \\
\hline
\end{tabular}

Concerning familiarity with the disease, it was observed that $88.8 \%$ of the sample had already heard or read about epilepsy (Table 1). This proportion is approximately $80 \%$ of $\mathrm{G}_{1} ; 92 \%$ of $\mathrm{G}_{2}$ and $97 \%$ of $\mathrm{G}_{3}(\mathrm{p}<0,001)$. The majority of the respondents $(67 \%)$ know someone with epilepsy. No difference was observed between the groups studied. Moreover, almost $60 \%$ of the sample have already witnessed a seizure, with a higher proportion in $\mathrm{G}_{1}(67 \%)$.

Among the possible causes of epilepsy proposed in the questionnaire, $72.4 \%$ of the respondents correlated epilepsy with brain disease (Table 2). Other causes marked by the volunteers were use of drugs $(37.6 \%)$, mental disease $(28.8 \%)$, hereditary $(26.3 \%)$, congenital abnormalities (25.2\%) and accidents (22.0\%). Only $11.3 \%$ of the sample studied did not know what could cause epilepsy among the options proposed in the questionnaire ( $\mathrm{G}_{1}=11.0 \% ; \mathrm{G}_{2}=13.6 \% ; \mathrm{G}_{3}=6.0 \%$; $\mathrm{p}=0.04$ ). In the subgroups analysis it was observed that $G_{3}$, the group of university students with more than 2 years at university, were more aware of causes such as use of drugs, traumatic accidents, congenital abnormalities and brain diseases.

When asked about epilepsy treatment, only 38 volunteers ( $4.6 \%)$ marked that there is no therapy, 27 of them belonging to $\mathrm{G}_{1}(9.0 \%)$ and 11 to $\mathrm{G}_{2}(2.9 \%)$ (Table 2). In addition, $\mathbf{2 2 . 4 \%}$ of $\mathrm{G}_{1}$ respondents did not know what the treatment was $(p<0.001)$, whereas this ratio was $9.7 \%$ in $\mathrm{G}_{2}$ and $2.7 \%$ in $\mathrm{G}_{3}$. Only 21 individuals $(2.5 \%)$ considered that teas and medicinal herbs were therapeutic options for epileptics, 16 belonging to $\mathrm{G}_{1}, 3$ to $\mathrm{G}_{2}$ and 2 to $\mathrm{G}_{3}$. In total, $22.7 \%$ of the population studied acknowledged that there is surgical treatment, and more than $80 \%$ pointed to pharmacology therapy. $\mathrm{G}_{3}$ was the group in which we noticed the best answers for the treatment.

In relation to the attitudes of the population studied dealing with a seizure, it was found that $49.3 \%$ of the individuals worry about removing objects that could hurt the sick person during the seizure (Table 2). The idea of inserting something inside the patient's mouth during the seizure was mentioned by $37.1 \%$ of the respondents. Attitudes such as keeping away from the person or throwing water on them were marked by only a small fraction of the sample, $1.1 \%$ in both the questions. Besides that, the idea of holding the patient trying to contain them was observed in a larger proportion of $\mathrm{G}_{1}(20.1 \%)$, the mean 
Table 3. Attitudes toward a person with epilepsy ( $n=832)$.

\begin{tabular}{lccccc}
\hline & Total & $\mathrm{G} 1$ & $\mathrm{G} 2$ & $\mathrm{G}_{3}$ & $\mathrm{p}$ \\
\hline Think epilepsy is a contagious disease & $1.9 \%$ & $4.7 \%$ & $0.5 \%$ & 0 & $<0.001$ \\
Think the patients with epilepsy usually have severe psychiatric disease & $25.4 \%$ & $47.8 \%$ & $15.1 \%$ & $6.7 \%$ & $<0.001$ \\
Judge necessary that children with epilepsy study in special classes & $16.1 \%$ & $36.8 \%$ & $5.5 \%$ & $2.0 \%$ & $<0.001$ \\
Would employ someone with epilepsy & $83.3 \%$ & $70.9 \%$ & $90.3 \%$ & $90.0 \%$ & $<0.001$ \\
Would marry someone with epilepsy & $75.5 \%$ & $59.5 \%$ & $85.3 \%$ & $81.3 \%$ & $<0.001$ \\
\hline
\end{tabular}

Table 4. Familiarity with epilepsy in different studies.

\begin{tabular}{|c|c|c|c|c|c|}
\hline Country & $\begin{array}{c}\text { Year of } \\
\text { publication }\end{array}$ & Population & $\begin{array}{l}\text { Heard or read } \\
\text { about epilepsy }\end{array}$ & $\begin{array}{l}\text { Witnessed an } \\
\text { epileptic seizure }\end{array}$ & $\begin{array}{c}\text { Knew someone } \\
\text { with epilepsy }\end{array}$ \\
\hline USA $^{1}$ & 1980 & General & $95 \%$ & $59 \%$ & $63 \%$ \\
\hline Finland $^{2}$ & 1980 & General & $95 \%$ & $45 \%$ & $49 \%$ \\
\hline Italy ${ }^{3}$ & 1985 & General & $73 \%$ & $52 \%$ & $61 \%$ \\
\hline Denmark $^{4}$ & 1992 & General & $97 \%$ & $50 \%$ & $60 \%$ \\
\hline Tanzania 5 & 1993 & General & - & $66 \%$ & - \\
\hline Taiwan $^{6}$ & 1995 & General & $87 \%$ & $56 \%$ & $70 \%$ \\
\hline \multirow[t]{4}{*}{ Brazil $^{7}$} & 1998 & General & $88 \%$ & $73 \%$ & $69 \%$ \\
\hline & & $\begin{array}{c}\text { First year college } \\
\text { student }\end{array}$ & $100 \%$ & $34 \%$ & $47 \%$ \\
\hline & & Non-medical students & $100 \%$ & $77 \%$ & $71 \%$ \\
\hline & & Medical students & $100 \%$ & $97 \%$ & $92 \%$ \\
\hline India ${ }^{8}$ & 2000 & General & $98 \%$ & - & $45 \%$ \\
\hline Hungary ${ }^{9}$ & 2001 & General & $93 \%$ & $55 \%$ & $51 \%$ \\
\hline Hong Kong ${ }^{10}$ & 2002 & General & $58 \%$ & $55 \%$ & $19 \%$ \\
\hline New Zealand" & 2002 & General & $96 \%$ & $67 \%$ & $76 \%$ \\
\hline Canada $^{12}$ & 2002 & University students & $91 \%$ & $48 \%$ & $57 \%$ \\
\hline Korea $^{13}$ & 2003 & General & $93 \%$ & $55 \%$ & - \\
\hline USA $^{14}$ & 2003 & General & - & $51 \%$ & $30 \%$ \\
\hline \multirow[t]{2}{*}{ Brazil $^{15}$} & 2004 & $\begin{array}{l}\text { First year university } \\
\text { students }\end{array}$ & $88 \%$ & $39 \%$ & - \\
\hline & & $\begin{array}{l}\text { Last year university } \\
\text { students }\end{array}$ & $95 \%$ & $55 \%$ & - \\
\hline \multirow{3}{*}{$\begin{array}{l}\text { Brazil } \\
\text { (present study) }\end{array}$} & 2007 & Non university students & $80.2 \%$ & $67.2 \%$ & $67.2 \%$ \\
\hline & & $\begin{array}{l}\text { University students } \\
\text { until the second } \\
\text { year of the course }\end{array}$ & $92.2 \%$ & $50.7 \%$ & $67.6 \%$ \\
\hline & & $\begin{array}{l}\text { University students } \\
\text { from the third year } \\
\text { to graduates }\end{array}$ & $97 \cdot 3 \%$ & $58.7 \%$ & $66.0 \%$ \\
\hline
\end{tabular}

ratio being $11.4 \%$. In the post-ictal period, the majority of the sample $(94.5 \%)$ believes that the patient should rest. However, $10 \%$ of $\mathrm{G}_{1}$ mentioned that epileptics should exercise after the seizure.

The questions that aimed at evaluating stigma among people interviewed are shown in Table 3. Generally, a greater proportion of stigma and negative attitudes was observed in G1. Only 16 (1.9\%) people believe that epilepsy is a contagious disease, 14 belonging to $G_{1}$ and 2 to $G_{2}$ ( $\left.p<0.001\right)$. Almost $50 \%$ of the $\mathrm{G}_{1}$ respondents believe that patients with epilepsy usually have severe psychiatric disease $\left(\mathrm{G}_{2}=15.1 \%\right.$ and $\mathrm{G}_{3}=6.7 \%$, $\left.\mathrm{p}<0.001\right)$. When asked whether they would offer a job to an epileptic, $83.3 \%$ declared that they 
would ( $\left.G_{1}=70.9 \% ; G_{2}=90.3 \% ; G_{3}=90.0 \% ; p<0.001\right)$.

In the analysis of the group of non-university students (G1) it was possible to observe that: the younger volunteers witnessed less seizures $\left(\mathrm{G}_{1} \mathrm{~A}=38.6 \%\right.$, $\mathrm{G} 1 \mathrm{~B}=70.9 \%$; $\mathrm{G}_{1} \mathrm{C}=73.8 \%$; $\left.\mathrm{p}<0.001\right)$; these younger people also are less aware of the use of drugs as a potential causal agent in developing a seizure. $\left(G_{1} A=22.7 \%\right.$; $\left.\mathrm{G} 1 \mathrm{~B}=41.2 \% ; \mathrm{G}_{1} \mathrm{C}=45.8 \% ; \mathrm{p}=0.02\right)$; most of $\mathrm{G}_{1} \mathrm{~A}(43.2 \%)$ believe that introducing something inside the mouth of the sick individual during a seizure is the right attitude when dealing with a seizure, while removing objects that could hurt the patient is the most prevalent choice in $\mathrm{G}_{1} \mathrm{~B}(48.6 \%)$ and $\mathrm{G}_{1} \mathrm{C}(35.5 \%)(\mathrm{p}=0.01)$; only $45.8 \%$ of $\mathrm{G}_{1} \mathrm{C}$ respondents would marry someone with epilepsy, this figure reaching $72.7 \%$ in $\mathrm{G}_{1} \mathrm{~A}$ and $65.5 \%$ in $\mathrm{G}_{1} \mathrm{~B}$.

\section{DISCUSSION}

This study aimed to evaluate awareness, attitudes and stigmas concerning epilepsy among the population of a city in Rio Grande do Sul, Brazil. Questionnaires that evaluate the perception of epilepsy in many different social segments have been used by a great number of authors ${ }^{1-15}$. Although many limitations have been observed such as understanding the questions, difficulty in achieving the right answer since there is a broad range of epilepsies, the tendency is to not expose negative positions on the subject and the non-validation of the instrument ${ }^{23}$. Recently, a scale to evaluate stigma in epilepsy has been developed $^{24,25}$. This will help to obtain more reliable data for this type of study.

It has been clearly observed that the level of education influences the answers about the disease and leads to less pejorative attitudes to persons with epilepsy, corroborating with other researches designed for similar purposes, ${ }^{4-11,13-15}$. It is inferred that populations with a lower level of education and a lower income probably also have less access to information concerning epilepsy and this contributes to maintaining erroneous concepts about the disease. This happens mainly due to lack of information in the media accessible to laypeople.

Table 4 shows the differences obtained in the answers about familiarity with the disease in many countries. It is observed that, although many people have already seen a seizure and know someone who suffers from the disease, the non-college population of Caxias do Sul is one of the least informed populations about the disease, with proportions similar to people in Hong Kong ${ }^{10}$ and Italy ${ }^{3}$. Besides that, when we compare this group $\left(\mathrm{G}_{1}\right)$ to the general population sample of Campinas, Brazil, obtained in the 9o's, no improvement has been observed in the level of familiarity with the disease after more than a decade.

Information campaigns are essential to change people's current thinking about epilepsy. In a study carried out in the United States ${ }^{1}$ comparing the changes in the perception of epilepsy among the population studied between 1949-1979, it was observed that the proportion of people who agreed that epileptics should be included in the labor market changed from $45 \%$ in 1949 to $79 \%$ in 1979 and that $59 \%$ of the people who thought that epilepsy was not a form of mental insanity in 1949 rose to $92 \%$ in 1979. Furthermore, research studies carried out in Korea ${ }^{13}$ and Hungary ${ }^{9}$ demonstrated that educational campaigns are effective in changing knowledge about epilepsy among the population and diminish the negative attitudes against patients with this disease.

About witnessing a seizure, it is observed that a higher proportion of the non-university group ( $\left.\mathrm{G}_{1}\right)$ said that they have already seen a seizure when compared to the university groups ( $\mathrm{G}_{2}$ and $\left.\mathrm{G}_{3}\right)$ and to other populations studied in other countries (Table 4). However, this statement could be wrong due to a possible incapacity of this population to recognize a real seizure. These proportions were also observed in the study of Santos and coworkers ${ }^{7}$, in which the proportion of witnessing a seizure was $34 \%$ in the non-university population against $73 \%$ in the general population. Another aspect observed is that the young adults (17-3oyrs) say they have witnessed more convulsive seizures than older people, a fact observed in other studies ${ }^{4,11}$.

In general, the groups with a higher level of education have obtained better answers about the knowledge of the causes and treatment of epilepsy. Nevertheless, it is observed that $32 \%$ of those interviewed with a higher level of education ( $\left.\mathrm{G}_{3}\right)$ correlate mental disease as a cause of epilepsy. This proportion is higher than the one observed in other countries such as in Canada ${ }^{12}(9 \%)$, Thailand ${ }^{16}(18 \%)$ and in the general Brazilian population in $1998^{7}(22 \%)$. Studies demonstrated that the proportion of the population that believes that epilepsy is a mental disease is $27 \%$ in India ${ }^{8}, 8 \%$ in Italy ${ }^{3}$ and $5 \%$ in Campinas, Brazil7.

The idea of introducing objects into the mouth to protect the tongue has been observed in a large part of the groups $\left(\mathrm{G}_{1}=33 \% ; \mathrm{G}_{2}=39 \% ; \mathrm{G}_{3}=38 \%\right)$. A recent Brazilian study demonstrated that $71 \%$ of the first-year students of health-related disciplines and $32 \%$ of the last year follow this practice ${ }^{15}$. Moreover, 
in a study that aimed to evaluate the knowledge of epileptic patients regarding their disease demonstrated that $41 \%$ of them take the same attitude ${ }^{26}$. These data suggest that there is lack of information about assistance and safe handling of a seizure in both the general population and in the patient's knowledge, since this attitude can harm the oral mucous and close the patient's airways.

Knowledge about the disease helps to diminish the negative attitudes toward epileptics. It is observed that besides the population being less informed about epilepsy, the non-university educated are those that have more stigmas attached to their culture. In a study performed on the parents of epileptic children, it has been demonstrated that $72 \%$ of the parents feel fear after the disease is diagnosed in their children, $27 \%$ felt scared, $33 \%$ sad and anxiety was reported by $27 \%{ }^{19}$. Furthermore, problems arose in accepting the disease and the parents expressed rejection (38\%), feelings of sorrow (94\%) and guilt (11\%). These feelings correlate with overprotection and permissive behavior, associated with insecurity in controlling the seizures. However, with appropriate instruction given to the parents in support group sessions, $94 \%$ of the parents reported improved knowledge about epilepsy, less stress related to the disease and now believe that they are capable of handling their children.

A study performed with epileptic patients due to temporal mesial sclerosis demonstrated that for $44 \%$ of them, work was the most affected area because of the seizures, followed by problems in the relationship and emotional sphere (30\%) and lack of independence in performing daily activities $(16 \%)^{27}$. In this same sample, $49 \%$ of the interviewed were either retired or receiving some sort of financial help from the government or did no work and $23 \%$ never had never worked at anything at all. In our study, approximately $17 \%$ of the interviewees would not employ a patient with epilepsy. Several reasons are given by some employers for not giving jobs to epileptics, such as: fear that the seizures could cause accidents, especially in industry; there is an assumption that epileptics have a lower working capacity and, therefore, low productivity $^{28}$.

In conclusion, this study suggests that there is still lack of information about epilepsy among the Brazilian population, especially among the non-university students. Educational programs in the media should be carried out to undo the myths and stigmas present in society, as well as informing about the treatments and causes of the disease.

\section{REFERENCES}

1. Caveness WF, Gallup GH, Jr. A survey of public attitudes toward epilepsy in 1979 with an indication of trends over the past thirty years. Epilepsia 1980;21:509-518.

2. Iivanainen M, Uutela A, Vilkkumaa I. Public awareness and attitudes toward epilepsy in Finland. Epilepsia 1980;21:413-423.

3. Canger R, Cornaggia C. Public attitudes toward epilepsy in Italy: results of a survey and comparison with U.S.A. and West German data. Epilepsia 1985;26:221-226

4. Jensen R, Dam M. Public attitudes toward epilepsy in Denmark. Epilepsia 1992;33:459-463.

5. Rwiza HT, Matuja WB, Kilonzo GP, et al. Knowledge, attitude, and practice toward epilepsy among rural Tanzanian residents. Epilepsia 1993;34:1017-1023.

6. Chung MY, Chang YC, Lai YH, Lai CW. Survey of public awareness, understanding, and attitudes toward epilepsy in Taiwan. Epilepsia 1995;36:488-493.

7. Santos IC, Guerreiro MM, Mata A, et al. Public awareness and attitudes toward epilepsy in different social segments in Brazil. Arq Neuropsiquiatr 1998;56:32-38.

8. Radhakrishnan K, Pandian JD, Santhoshkumar T, et al. Prevalence, knowledge, attitude, and practice of epilepsy in Kerala, South India. Epilepsia 2000;41:1027-1035.

9. Mirnics Z, Czikora G, Zavecz T, Halasz P. Changes in public attitudes toward epilepsy in Hungary: results of surveys conducted in 1994 and 2000. Epilepsia 2001;42:86-93.

10. Fong CY, Hung A. Public awareness, attitude, and understanding of epilepsy in Hong Kong Special Administrative Region, China. Epilepsia 2002;43:311-316.

11. Hills MD, MacKenzie HC. New Zealand community attitudes toward people with epilepsy. Epilepsia 2002;43:1583-1589.

12. Young GB, Derry P, Hutchinson I, et al. An epilepsy questionnaire study of knowledge and attitudes in Canadian college students. Epilepsia 2002;43:652-658.

13. Kim MK, Kim IK, Kim BC, Cho KH, Kim SJ, Moon JD. Positive trends of public attitudes toward epilepsy after public education campaign among rural korean residents. J Korean Med Sci 2003;18:248-254.

14. Kobau R, Price P. Knowledge of epilepsy and familiarity with this disorder in the U.S. population: results from the 2002 HealthStyles Survey. Epilepsia 2003;44:1449-1454.

15. Fonseca LC, Tedrus GM, Costa AC, Luciano PQ, Costa KC. [Knowledge and attitude toward epilepsy among health area students]. Arq Neuropsiquiatr 2004;62:1068-1073.

16. Kankirawatana P. Epilepsy awareness among school teachers in Thailand. Epilepsia 1999;40:497-501.

17. McLin WM, de Boer HM. Public perceptions about epilepsy. Epilepsia 1995;36:957-959.

18. Suurmeijer TP, Reuvekamp MF, Aldenkamp BP. Social functioning, psychological functioning, and quality of life in epilepsy. Epilepsia 2001;42:1160-1168

19. Souza EA, Nista CR, Scotoni AE, Guerreiro MM. [Feelings and behaviors of parents of children with epilepsy]. Arq Neuropsiquiatr 1998;56:39-44.

20. Gomes MM. Doctors' perspectives and practices regarding epilepsy. Arq Neuropsiquiatr 2000;58:221-226.

21. Marchetti RL, de Castro AP, Daltio CS, Cremonese E, Ramos JM, Neto JG. Attitudes of Brazilian psychiatrists toward people with epilepsy. Epilepsy Behav 2004;5:999-1004.

22. Antoniuk SA, Santos LHC, Baú C, et al. Atitudes e preconceitos sobre epilepsias em uma população de pais e professores de Curitiba. J Epilepsy Clin Neurophysiol 2005;11:49-52.

23. Gajjar M, Geva E, Humphries T, Peterson-Badali M, Otsubo H. A new scale to assess culture-specific beliefs and attitudes about epilepsy. Epilepsy Behav 2000;1:235-255.

24. Fernandes PT, Salgado PC, Noronha AL, Barbosa FD, Souza EA, Li LM Stigma scale of epilepsy: conceptual issues. J Epilepsy Clin Neurophysiol 2004;10:213-218.

25. Salgado PC, Fernandes PT, Noronha AL, Barbosa FD, Souza EA, Li LM [The second step in the construction of a stigma scale of epilepsy.]. Arq Neuropsiquiatr 2005;63:395-398.

26. Long L, Reeves AL, Moore JL, Roach J, Pickering CT. An assessment of epilepsy patients' knowledge of their disorder. Epilepsia 2000;41:727-731.

27. Alonso NB, Silva TI, Westphal AC, et al. Depressive symptoms and quality of life in people with epilepsy related to mesial temporal sclerosis. J Epilepsy Clin Neurophysiol 2005;11:117-122.

28. Sarmento MR, Minayo-Gomez C. [Epilepsy, epileptics, the work: conflicting relations]. Cad Saude Publica 2000;16:183-193. 